\title{
TUDOMÁNYOS KONFERENCIA
}

\author{
Scientific Conference
}

\section{Kukoricát jövedelmezóen \\ Négyhelyszínes országos konferencia 2009. február 11., 12. és 18., 19-én a kukoricáról}

Az AGROFÓRUM szakmai havi lap 2005-ben elindított egy fórum jellegú rendezvénysorozatot „Útkeresés” címmel.

Ennek volt újabb állomása, ezúttal a XVII. konferencia, amelynek témájául a kukoricatermesztés jövedelmi viszonyait, illetve a jövedelmezóség feltételeinek vizsgálatát és elemzését választottuk.

Választ kerestünk arra, hogy az egyes technológiai elemek jól vagy rosszul történô alkalmazásával, a fajtaválasztással mennyit nyerhetünk, vagy mennyit veszíthetünk. Kerestük a megoldásokat a változó piaci viszonyok között a termelői, kereskedői magatartásokra. Mindezt négy helyszínen: Keszthelyen, Debrecenben, Mosonmagyaróváron és Szarvason.

A konferencia ötletét és mottóját dr. 'Sigmond Eleknek a múlt század elején megfogalmazott és ma is időszerú - lényeglátó - gondolatai adták, mely szerint: „... a növények termelése szempontjából nem lehet az a fö cél, hogy maximális termést produkáljunk, hanem hogy maximális tiszta jövedelmet arassunk.” (dr. 'Sigmond Elek: 1930. A mezőgazdasági növények termelési tényezôi. Szent István Társulat Könyvkiadó, Budapest).

Ez a nyolcvan évvel ezelôtt, az Országos Chemiai Intézet vezetôje által írott - közgazdaságilag ma is idôtálló - szentencia indított bennünket arra, hogy a tudomány és a gyakorlat kapcsolatára alapozva, együtt keressük a jövedelmezó kukoricatermesztés technológia, és gazdasági megoldásait.

Társrendezóink a Gabonatermesztôk Országos Szövetsége, a Szekszárdi Növény Zrt., a FARMIT Agropoltál, valamint az adott város felsóoktatási intézménye. 
A program lényegében azonos volt valamennyi helyszínen:

- Az ország egyes régióinak, vagy a térségéhez tartozó régiók kukoricatermesztésének bemutatása.

- Mennyit nyerhetünk az okszerú tápanyag-gazdálkodással? - kérdeztük az oktatási intézmények szakembereitôl.

- Mennyit veszíthetünk, ha nem jól választunk fajtát? - volt a következô témánk.

- Elôadás hangzott el a precíziós gazdálkodás előnyeirôl.

- Vizsgáltuk a kukoricatermesztés jövedelmezóségi viszonyait.

- Végül a gabonakereskedők részvételével megvitattuk, hogy milyen értékesítési stratégiák biztosíthatják a gazdák számára a legkedvezőbb bevételi lehetôségeket.

Azonos volt a program, de váltott elôadókkal. Ahol helyben volt felkészült szakember, ott ôt kértük fel az elôadás megtartására.

Örömünkre szolgált, hogy az MTA Növénytermesztési Bizottságának tagjai közül többen is vállaltak előadást, illetve néhányan, mint intézményvezetők a konferenciák megnyitásával adtak rangot a rendezvénynek.

Keszthelyen prof. Kocsis László dékán-helyettes az intézmény oktatási feladatairól számolt be megemlítve, hogy az agrároktatás milyen, a kor követelményeihez igazodó tárgyakkal bóvült. Debrecenben prof. Nagy János centrumelnök megnyitójában kiemelte, hogy az egyetem mindig szívesen látja a szakembereket és örömmel ad helyet minden olyan rendezvénynek, amely az agrárium érdekeit szolgálja. A rendelkezésére álló idôt betartva azért a kukoricatermesztés sarkalatos problémáiról is szót ejtett, vagyis a termésingadozások mértékérôl, amellyel egyúttal az utána következó előadások alaphangját is megadta. (Nem titkolt örömmel vettük az Agrofórum szakmai színvonalát méltató szavait. Ezúttal is köszönjük.) Mosonmagyaróváron prof. Schmidt Rezső dékán nyitotta meg a konferenciát. Kérésünket elfogadva bemutatta az egyetem Mezőgazdasági és Élelmiszertudományi Karának szervezetét, az oktatási stratégiát, a gazdászképzés mellett az újabb szakok indításának igényét és okát. Itt is szívesen látott vendégek, illetve rendezôtársak voltunk, akárcsak Szarvason, ahol Takácsné dr. Hájos Mária dékánasszony megnyitójába ugyancsak sok információt súrített. Beszámolt az intézmény új státusáról (Szent István Egyetem, Tessedik Sámuel Egyetemi Központ) az oktatási irányokról és a jövôbeni elképzelésekről. Említést tett a korábbi rendezvényeinkről és reményét fejezte ki, hogy Szarvason is hasonlóan sikeres lesz a konferencia, mint az elôző helyszíneken. 
A szigorú értelemben vett szakmai előadásokat a térségi kukoricatermesztésről Keszthelyen és Debrecenben Lukács József, a Mezôgazdasági Szakigazgatási Hivatal Központ osztályvezetője, illetve Mosonmagyaróváron $d r$. Gergely István tanszékvezetô tartotta. Dr. Széll Endre akadályoztatása miatt, helyette $d r$. Szél Sándor ismertette Szarvason a Dél-alföldi régió meghatározó szerepét a kukoricatermesztésben.

A tápanyag-gazdálkodásnak mindenütt volt szakavatott múvelője és előadója. Keszthelyen prof. Kismányoky Tamás tanszékvezető, Debrecenben prof. Pepó Péter tanszékvezetô, Mosonmagyaróváron $d r$. Kajdi Ferenc egyetemi docens, Szarvason pedig prof. Izsáki Zoltán tanszékvezető. Köszönjük valamennyiük rangos előadását. Szinte egybehangzó megállapításuk volt, hogy a kukorica tápanyagigényét a talajvizsgálatokra alapozott, harmonikus tápanyagellátással lehet csak biztosítani, ami egyben a jövedelmezóségnek is feltétele.

A fajtaválasztás kérdését, az államilag elismert fajtákkal végzett tájkísérletek alapján elemezte Petőházi Tamás, a Gabonatermesztők Országos Szövetségének foótitkára. Mennyit veszíthetünk, ha nem jól választunk fajtát? Kérdésre a válasz: akár százezer Ft-ot is meghaladó lehet a veszteségünk, ha nem figyelünk az adott tájban elérhetô terméseredményekre, a fajták tenyészidejére, a vízleadás ütemére, a szárszilárdságra és még néhány agronómiailag fontos terméselemre.

Osztatlan sikert könyvelhetett el mindenütt prof. Reisinger Péter tanszékvezető, aki valamennyi helyszínen a precíziós gazdálkodás előnyeirôl beszélt. Óriási tartalékok vannak ebben a ma még kuriózum számba menô technológiában, amely a vetéstôl kezdve, a gyomirtáson keresztül, a tápanyag-gazdálkodással folytatva, olyan ökonómiailag is megalapozott megoldásokat kínál, amelyek a jövố mezőgazdaságát forradalmasíthatják.

Hasonló érdeklődés fogadta $d r$. Potori Norbert osztályvezetô elôadását, aki az Agrárgazdasági Kutató Intézetben végzett kutatások eredményeként a kukoricatermesztés jövedelmezôségének közgazdasági feltételeit elemezte. Beszélt a kereskedelmi lehetőségekrôl és korlátokról, a szállítási költségek meghatározó szerepérôl. Bemutatta a változó költségek alakulását az elmúlt évek viszonylatában, amelyek eldönthetik, hogy milyen termésszint mellett beszélhetünk jövedelmező kukoricatermesztésrôl.

Az Útkeresés rendezvénysorozat utolsó programját $d r$. Csibor István a Szekszárdi Növény Zrt. igazgatója vezette, amelyen a „fórum” hagyományait követve megszólaltak a kereskedelem képviselői és a termelők. Csibor dr. beszélgető 
partnere a kereskedelem oldaláról Keszthelyen és Szarvason Bidló Gábor ügyvezetố volt, a Hungária Gabona Kft. képviseletében. Debrecenben Otrok György a Concordia Kereskedóház Kft. ügyvezetôje beszélt a kereskedói magatartásról és a javasolt termelői stratégiákról. Mosonmagyaróváron Kiss Péter a Töepfer Magyarország Kft. ügyvezetôje ismertette - a céget is bemutatva azt a kereskedelempolitikát, amely ebben a bizonytalan piaci helyzetben a legcélravezetôbb.

A kereskedôk közel azonos stratégiát javasoltak a termelóknek, vagyis az áru egyharmadát eladni, amikor az ár kedvezônek túnik. A másik harmadot fix árra célszerú leszerződni, amely ad egy értékesítési biztonságot, és a harmadik harmadot tárolni, amelyet akkor kell eladni, amikor az árak a piaci kereslet következtében kedvezó irányt vesznek.

A termelők kérdeztek is, hallgattak is. Mindenütt a bizonytalan jövő árnyékolta be a rendezvények hangulatát. Mi lesz a készletekkel? Mozdulnak-e az árak? Kell-e egyáltalán a kukorica, amikor mindenütt túltermelés volt 2008ban? Ha nem tudjuk a választ, akkor adódik a következô kérdés: mennyi kukoricát vessünk tavasszal?

Ha ugyanannyit, akkor esetleg tetézzük a gondjainkat. Ha csökkentjük a területet, akkor mit vessünk helyette? Voltak felvetések: fehérjenövényeket stb.

Ezeknek ismerjük számtalan elônyét, csak éppen - több évtized óta - ez irányban mégsem mozdultunk. Nem vitt rá bennünket a kényszer.

Abban azért mégiscsak egyetértés volt, hogy kukoricát igenis akarunk termelni, legalábbis a vetésterület meghatározó hányadán.

Erre vagyunk berendezkedve és ráhangolódva is.

Egyet azonban világosan kell látni: termelni csak jövedelmezóen szabad. Ehhez szerettünk volna konferenciasorozatunkkal hozzájárulni.

Végezetül köszönettel tartozik az AGROFÓRUM munkatársai nevében is, valamennyi elôadónak és résztvevőnek a rendezvénysorozat moderátora

Dr. Bódis László 